\title{
ANALISIS KADAR VITAMIN C \\ PADA BUAH NAGA MERAH (Hylocereus lemairei (Hook.) Britton \& Rose) \\ DAN BUAH NAGA PUTIH (Hylocereus undatus (Haw.) Britton \& Rose) \\ DI KEPULAUAN RIAU MENGGUNAKAN SPEKTROFOTOMETRI ULTRAVIOLET
}

\section{ANALYSIS OF VITAMIN C LEVELS \\ IN RED DRAGON (Hylocereus lemairei (Hook.) Britton \& Rose) \\ AND WHITE DRAGON (Hylocereus undatus (Haw.) Britton \& Rose) FRUITS IN RIAU ISLANDS USING UV-VIS SPECTROPHOTOMETRY}

\author{
Suhaera, Suci Fitriani Sammulia, Hayatul Islamiah \\ Prodi Sarjana Farmasi STIKes Mitra Bunda Persada, Jalan Seraya No1 Teluk Tering \\ Kota Batam, Kepulauan Riau 29441, Indonesia \\ Email: esuhaera@gmail.com (Suhaera)
}

\begin{abstract}
ABSTRAK
Buah naga merupakan salah satu buah yang mengandung vitamin C. Telah dilakukan penelitian tentang analisis kadar vitamin $\mathrm{C}$ pada buah naga merah (Hylocereus lemairei (Hook.) Britton \& Rose) dan buah naga putih (Hylocereus undatus (Haw.) Britton \& Rose) di Batam menggunakan spektrofotometri ultraviolet. Pada penelitian ini daging buah naga segar dihaluskan dengan blender, disaring, dan dilakukan uji kualitatif terlebih dahulu. Setelah itu dilakukan uji kuantitatif untuk menentukan kadar vitamin C menggunakan spektrofotometri ultraviolet dengan panjang gelombang $264 \mathrm{~nm}$ dan vitamin $C$ sebagai pembandingnya. Hasil penelitian ini menunjukan kadar vitamin $C$ pada buah naga putih lebih tinggi dibanding buah naga merah.
\end{abstract}

Kata kunci: buah naga, vitamin C, spektrofotometri ultraviolet.

\begin{abstract}
Dragon fruit is rich with vitamin C. A study to analyze vitamin C levels in red dragon (Hylocereus lemairei (Hook.) Britton \& Rose) and white dragon (Hylocereus undatus (Haw.) Britton \& Rose) fruits originated from Batam using ultraviolet spectrophotometry has been carried out. In this study, fresh dragon fruits were mashed and blended, filtered, and qualitatively analyzed for vitamin C. The quantitative study was carried out to determine vitamin C levels using ultraviolet spectrophotometry at a wavelength of $264 \mathrm{~nm}$ and vitamin $C$ as the reference compound. The results of this study showed that vitamin $C$ level in white dragon fruits were higher than that of red dragon fruit.
\end{abstract}

Key words: dragon fruits, ultraviolet spectrophotometry, vitamin C. 


\section{Pendahuluan}

Indonesia merupakan wilayah yang beriklim tropis dan berada di daerah khatulistiwa. Indonesia memungkinkan tumbuhnya berbagai macam tumbuh-tumbuhan dengan subur seperti buah-buahan. Salah satunya yaitu pitaya atau lazim juga disebut buah naga.

Buah naga merupakan tanamam jenis kaktus yang berasal dari Amerika Tengah, Amerika Selatan, dan Meksiko (Astarini, 2010). Empat spesies buah naga yang umum terdapat di Indonesia adalah buah naga merah dengan daging buah putih (Hylocereus undatus), buah naga kuning (Selenicerius megalanthus), buah naga kulit merah dengan daging buah merah (Hylocereus polyrhizus) dan buah naga kulit merah dengan daging buah sangat merah (Hylocereus costaricencis) (Dharmayudha dan Anthara, 2011).

Buah naga bermanfaat untuk mengobati berbagai jenis penyakit yaitu dapat menurunkan kadar kolesterol, penyeimbang kadar gula darah, mencegah kanker usus, menguatkan fungsi ginjal dan tulang, menguatkan daya kerja otak, meningkatkan ketajaman mata serta sebagai bahan kosmetik (Rahmawati \& Mahajoeno, 2010).

Buah-buahan mengandung berbagai macam vitamin, salah satunya adalah vitamin C. Vitamin C diperlukan oleh tubuh, agar tubuh dapat melakukan proses metabolisme dan pertumbuhan yang normal, vitamin C juga dapat berperan sebagai antioksidan yang merupakan satu mekanisme pertahanan yang paling penting untuk melawan radikal bebas (Andarwulan dan Koswara, 1992; Febrianti et al., 2016; Louarme dan Billaud, 2012). Kebutuhan vitamin C bagi orang dewasa adalah sekitar $60 \mathrm{mg}$, untuk wanita hamil $95 \mathrm{mg}$, anak-anak 45 mg, dan bayi $35 \mathrm{mg}$, namun karena banyaknya polusi di lingkungan antara lain adanya asap kendaraan bermotor dan asap rokok maka penggunaan vitamin C perlu ditingkatkan hingga dua kali lipatnya yaitu 120 mg (Putra, 2011).

Penelitian ini bertujuan untuk menentukan dan membandingkan kadar vitamin $\mathrm{C}$ yang terdapat pada buah naga merah dan naga merah putih. Sehingga penelitian yang dilakukan dapat mengetahui perbandingan kadar vitamin $\mathrm{C}$ pada buah naga merah dan buah naga putih.

Penentuan kadar vitamin C pada penelitian ini menggunakan metode 
spektrofotometri ultraviolet. Metode spektrofotometri dapat digunakan untuk penetapan kadar campuran dengan spektrum yang tumpang tindih tanpa melakukan pemisahan terlebih dahulu. Karena perangkat lunaknya mudah digunakan untuk instrumentasi analisis dan mikrokomputer, spektrofotometri banyak digunakan di berbagai bidang analisis kimia terutama farmasi (Arel et al., 2017).

\section{Metode Penelitian}

\section{Alat dan Bahan}

Alat-alat yang digunakan adalah timbangan analitik, corong, spatel, kertas saring, labu ukur, gelas ukur, cawan penguap, beaker glass, erlenmeyer, pipet ukur, batang pengaduk, blender, pipet mikro, tabung reaksi dengan raknya, dan seperangkat alat spektrofotometer. Sedangkan bahan yang digunakan adalah buah naga merah (Hylocereus polyrhizus), buah naga putih (Hylocereus undatus), larutan biru metilen, asam askorbat, natrium hidroksida 10\%, akuades, pereaksi Benedict, ferro sulfat $5 \%$, iodium, dan kalium permanganat.

\section{Jalannya Penelitian}

1. Pengambilan sampel

Sampel yang digunakan adalah buah naga merah dan buah naga putih yang diperoleh dari Perkebunan Barelang, Kota Batam, Kepulauan Riau.

2. Identifikasi sampel

Identifikasi sampel dilakukan di Herbarium Universitas Andalas, Jurusan Biologi, Fakultas FMIPA, Universitas Andalas.

3. Pengolahan sampel

Buah naga merah dan buah naga putih dikupas, dicuci bersih, dipotong kecil-kecil kemudian diblender. Setelah diblender, larutannya diambil untuk disaring lalu ditimbang sebanyak 5 g. Setelah itu filtratnya dimasukkan ke dalam labu ukur 100 $\mathrm{mL}$, dan ditambahkan akuades sampai tanda batas, kemudian dihomogenkan.

4. Uji kualitatif (Arel et al., 2017)

Sampel sebanyak $2 \mathrm{~mL}$ ditambahkan 4 tetes larutan biru metilen. Larutan dihangatkan hingga suhu $40{ }^{\circ} \mathrm{C}$. Terjadi warna biru tua yang dalam waktu 3 menit berubah menjadi lebih muda atau hilang.

Sampel sebanyak $2 \mathrm{~mL}$ ditambahkan 2 tetes natrium hidroksida 10\%. Kemudian larutan ditambahkan $2 \mathrm{~mL}$ ferro sulfat $5 \%$. Perubahan warna yang terjadi 
diamati, reaksi positif ditandai dengan terbentuknya warna kuning.

Sampel sebanyak $1 \mathrm{~mL}$ ditambahkan tetes demi tetes iodin 10\%. Warna iodin akan berkurang atau hilang \pm 3 menit.

Sampel sebanyak $1 \mathrm{~mL}$ ditambahkan beberapa tetes pereaksi benedict, dipanaskan di atas bunsen sampai mendidih. Sampel positif mengandung vitamin $\mathrm{C}$ ketika larutan bereaksi berubah menjadi warna merah bata.

Sampel sebanyak beberapa $\mathrm{mL}$ ditambahkan beberapa tetes kalium permanganat. Perubahan warna yang terjadi diamati. Reaksi positif ditandai dengan terbentuknya endapan coklat.

5. Pembuatan larutan induk vitamin C 100 ppm

Asam askorbat sebanyak $50 \mathrm{mg}$ ditimbang, kemudian dimasukkan ke dalam labu ukur $500 \mathrm{~mL}$ dan dilarutkan dengan akuabides sampai tanda batas.

6. Penetapan panjang gelombang serapan maksimum larutan vitamin $\mathrm{C}$

Larutan vitamin C 100 ppm dipipet sebanyak $5 \mathrm{~mL}$, kemudian dimasukkan ke dalam labu terukur 50 ml (konsentrasi 10 ppm). Akuabides ditambahkan sampai tanda batas dan dihomogenkan. Kemudian serapan maksimum diukur pada panjang gelombang 200-400 nm dengan menggunakan blanko akuabides.

7. Pembuatan kurva kalibrasi

Larutan vitamin C 100 ppm dipipet ke dalam labu ukur $50 \mathrm{~mL}$ masing-masing sebesar $2,3,4,5$, dan $6 \mathrm{~mL}(4,6,8$, 10, dan $12 \mathrm{ppm})$. Kemudian masing-masing larutan ditambahkan akuabides hingga tanda batas lalu dihomogenkan dan diukur serapannya pada panjang gelombang maksimum yang diperoleh.

8. Penentuan kadar sampel

Filtrat yang telah didapat setelah pengolahan sampel, diperlakuan tiap sampelnya sama, yaitu daging buah naga dihaluskan kemudian ditimbang 5 gram dan dimasukkan ke dalam labu ukur 100 mL. Kemudian sampel ditambahkan akuades sebagai pelarut hingga tanda batas dan disaring menggunakan kertas saring, lalu diencerkan dengan memipet larutan sampel dengan berbagai konsentrasi, dimasukkan ke dalam labu ukur 50 $\mathrm{mL}$ dan ditambah pelarut hingga tanda batas. Selanjutnya diukur serapannya dengan beberapa konsentrasi yang berbeda. 
Pengukuran dilakukan pada panjang gelombang maksimum yang didapat.

\section{Hasil dan Pembahasan}

Penelitian dilakukan dimulai dengan determinasi tanaman. Determinasi terhadap tanaman yang akan diteliti bertujuan untuk mendapatkan kebenaran identitas dari tanaman yang diteliti. Determinasi terhadap tanaman yang diteliti dilaksanakan di Herbarium Universitas Andalas, Jurusan Biologi, Fakultas FMIPA, Universitas Andalas. Dari hasil determinasi ini diperoleh bahwa spesimen tumbuhan tersebut adalah Hylocereus lemairei (Hook.) Britton \& Rose) (buah naga merah) dan Hyloceres undatus (Haw.) Britton \& Rose) (buah naga putih).

Sampel yang digunakan adalah buah naga yang diambil dari Perkebunan Barelang. Buah naga merupakan tanaman tropis dan sangat mudah beradaptasi terhadap lingkungan tumbuh dan perubahan cuaca. Pertumbuhan dan perkembangan tanaman buah naga ini akan lebih baik pada dataran rendah yaitu 0-100 Mdpl. Jika buah naga tumbuh baik pada dataran rendah, maka mutu buah naga pada dataran rendah lebih baik dibandingkan dengan dataran tinggi. Mutu buah naga dapat dilihat dari ukuran, berat, dan juga kemanisannya. Semakin bagus mutu buah naga maka kandungan gizi di dalamnya semakin tinggi juga, begitupun halnya dengan vitamin $\mathrm{C}$ yang dikandungnya. Vitamin $\mathrm{C}$ merupakan vitamin yang larut air, maka dari itu pada penelitian ini digunakan pelarut akuabides yang steril dengan tujuan untuk mengurangi resiko keberadaan zat pengotor dan bebas dari pirogen. Dari hasil uji kualitatif menunjukkan bahwa pada buah naga merah dan buah naga putih positif mengandung vitamin $\mathrm{C}$.

Larutan standar asam askorbat dibuat dengan konsentrasi 100 ppm, kemudian diencerkan menjadi 10 ppm untuk mengukur panjang gelombang serapan maksimum dan diperoleh hasilnya $264 \mathrm{~nm}$ dengan alat spektrofotometri UV-Visibel. Dari larutan induk 100 ppm dibuat sederetan konsentrasi 4, 6, 8, 10, dan $12 \mathrm{ppm}$ dan diukur absorbansinya dengan panjang gelombang $264 \mathrm{~nm}$. Kemudian dibuat kurva kalibrasi yang dibentuk dari data konsentrasi dan absorban. Persamaan regresi liniear dari kurva kalibrasi adalah $y=0,068 x-0,0164$ dengan nilai koefisien korelasi ( $r$ ) sebesar 0,998 yang 
menunjukan linearitas dari persamaan (Gambar 1).

Perlakuan tiap sampelnya sama. Sampel diukur serapannya pada panjang gelombang $264 \mathrm{~nm}$. Dari hasil perhitungan kadar vitamin $\mathrm{C}$, diperoleh hasil yaitu kadar vitamin $\mathrm{C}$ pada sampel buah naga putih lebih besar dibandingkan buah naga merah yaitu 0,3338 mg/g. Sedangkan kadar vitamin C pada buah naga merah adalah 0,3108 $\mathrm{mg} / \mathrm{g}$.

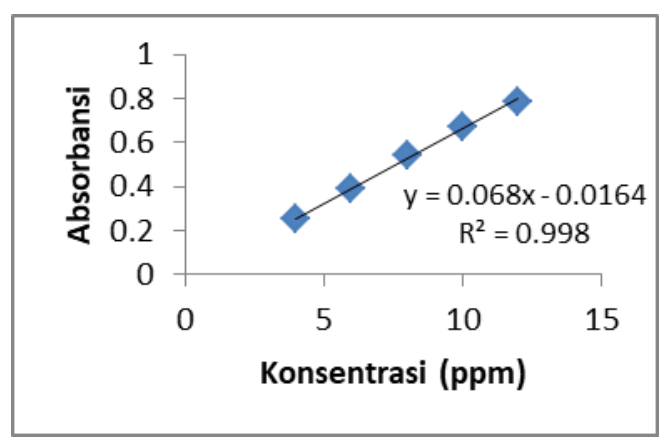

Gambar 1. Kurva baku larutan vitamin C.

\section{Simpulan}

Berdasarkan hasil penelitian bahwa kadar vitamin $C$ tertinggi terdapat pada buah naga putih dengan hasil $0,3338 \mathrm{mg} / \mathrm{g}$, sedangkan pada buah naga merah $0,3108 \mathrm{mg} / \mathrm{g}$. Untuk selanjutnya diharapkan dapat diteliti kadar vitamin C pada kulit buah naga merah dan buah naga putih.

\section{Daftar Pustaka}

Andarwulan, N. dan Koswara, S. 1992. Kimia Vitamin. Jakarta: CV Rajawali.
Arel, A., Martinus, B.A., Ningrum, S.A. 2017. Penetapan kadar vitamin $C$ buah naga merah (Hylocereus costaricensis (FAC Weber) Britton \& Rose) dengan metode spektrofotometri UV-Vis. Scientia: Jurnal Farmasi dan Kesehatan, 7(1):1-5.

Astarini, I.A. 2010. Uji viabilitas dan perkembangan serbuk sari buah naga putih (Hylocereus undatus), merah (Hylocereus polyrhizus) dan super merah (hylocereus costaricensis) setelah penyimpanan. Jurnal Biologi, 14(1):39-44.

Dharmayudha, A.A.G.O. dan Anthara, M.S. 2011. Identifikasi golongan senyawa kimia dan pengaruh 
ekstrak etanol buah naga daging putih (Hylocereus undatus) terhadap penurunan kadar glukosa darah serta bobot badan tikus putih jantan (Rattus novergicus) yang diinduksi aloksan. Buletin Veteriner Udayana, 5(1):31-40.

Febrianti, N., Yunianto, I., Dhaniaputri, R. 2016. Kandungan antioksidan asam askorbat pada buah-buahan tropis. BioWallacea Jurnal IImiah Biologi, 2(1):1-5.

Louarme, L. dan Billaud, C. 2012. Evaluation of ascorbic acid and sugar degradation products during fruit dessert processing under conventional or ohmic heating treatment. LWT- Food Science and Technology, 49(2):184-187.

Putra, A.A. 2011. Penetapan kadar vitamin C dari bawang putih (Allium sativum L.) secara titrasi 2,6-diklorofenol indofenol. Skripsi. Fakultas Farmasi, Universitas Sumatera Utara.

Rahmawati, B. dan Mahajoeno, E. 2010. Variasi morfologi, isozim, dan kandungan vitamin $\mathrm{C}$ pada varietas buah naga. Bioteknologi, 7(1):3544. 